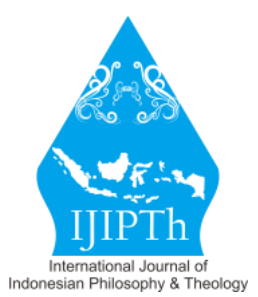

\title{
Dayak Tunjung Cosmology and the Theology of Communio Sanctorum An Exploration of Contextual Theology in Synthetic Model of Stephen B. Bevans
}

\author{
Yohanes Damianus \\ Member of Oblate of Mary Immaculate of Indonesian Province \\ Email: ydamianus@gmail.com
}

\begin{abstract}
The revelation of God through history is being permeated in human beings' culture. Eventually, its proclamation too brought in itself the cultural elements. Since, the culture itself is holy, because it is precisely part of the revelation, and one culture can be in dialogue with other (s) one because God has taken the culture as a context for His revelation. In missiology, theological reflection tries to offer further and define what the church has been doing since its presence, a practice of a contextual theological reflection. In this space of thought, the church doctrine on Communio Sanctorum will be in dialogue with a Dayak Tunjung cosmology. It will make a synthesis between theology and culture so that the two communities can live and grow together in their respective traditions. The synthetic model of contextual theology offered by Stephen B. Bevans will be used as a framework. The reflection will go to make a synthetic model of the theology of Dayak Tunjung cosmology and Communio Sanctorum in its three categories, mainly cosmological, ritual, and communal life. God, through his Holy Spirit, continuously renews the human beings together with their whole culture aspects.
\end{abstract}

Keywords: Cosmology, Communio Sanctorum, Loci-theologici, Missio Dei, Religiosity

\begin{abstract}
Abstrak: Pewahyuan Allah melalui sejarah sedang diserap dalam budaya manusia. Akhirnya, proklamasinya juga menghadirkan unsur-unsur budaya. Budaya itu sendiri adalah suci, karena itu persis bagian dari wahyu, dan satu budaya dapat berdialog dengan yang lain karena Tuhan telah mengambil budaya sebagai konteks untuk wahyu-Nya sendiri. Dalam misiologi, refleksi teologis mencoba menawarkan lebih jauh dan mendefinisikan apa yang telah dilakukan gereja sejak kehadirannya, sebuah praktik refleksi teologis kontekstual. Dalam ruang pemikiran ini, doktrin gereja tentang communio sanctorum akan berdialog dengan kosmologi Dayak Tunjung, upaya untuk membuat sintesis antara teologi dan budaya sehingga kedua komunitas dapat hidup dan tumbuh bersama dalam tradisi masing-masing. Model sintetis dari teologi kontekstual yang ditawarkan oleh Stephen B. Bevans akan digunakan sebagai kerangka kerja. Refleksi akan membuat model sintetis dari teologi kosakologi Dayak Tunjung dan communio sanctorum dalam tiga kategori, terutama kosmologis, ritual, dan kehidupan komunal. Tuhan, melalui Roh Kudus-Nya, terus memperbarui manusia bersama dengan seluruh aspek budaya mereka.
\end{abstract}

Kata kunci: Kosmologi, Communio Sanctorum, Loci-theologici, Missio Dei, Religiositas

\section{Introduction}

In the broad sense, theology is always a contextual one, to say that it is a result of the reflection due to its particular time, place, and problems exist. The result of the theological thinking in one time and place in many ways does not always fit a different period and era afterward. Theological reflection, even though not to say about all of its ideas, sometimes simply limited to its specific epoch and territory. For instance, what is considering booming in Europe and Latin America in one time is that it is not necessarily that the same theological concept and thought will be well accepted in Asia or Africa. So it is to say that the liberation theology in Latin America, either on its theological method or approach, 
doesn't always being easily applied everywhere in Asia or Africa. Since contain and message of theology is very much determined by its particular context where it has been reflected. Here lies the challenge for every particular church to continuously looking for what is the best way in terms of theological effort to make the Gospel message that can be delivered and well accepted by the people in their unique customs, traditions, cultures, and values.

So, it is in once side a challenge for the theologian to search for the right way. And answer toward many problems arise in their respective places. At the same time, it is an opportunity as well to renew and broaden some theological concepts which might not be able to give the correct answers to the nowadays people's thinking. As Taiwanese theologian Po Ho Huang (2011) mentioned, "theologians engaged with contextual theologies contend that all theologies were produced in response to the particular contexts as theologians and their faith communities confronted in different geographical locations and periods of human history."

The contextual theology, especially in the Asian context, was an eruption of third world contextual theologies after the Second World War. Again, in this idea, Huang (2011, p. 12) thought is worthy of being quoted again here where he said, "what was traditionally considered as pagan and profane experiences and cultures were lifted as profound sources for doing theology with a professed objective to transform Christian theology into a liberating power of the oppressed, the marginalized and the discriminated." The cultures and all the present human experience which we call as a context has become what Stephen Bevans (2016) said as the third source of theology or loci theologici besides the scripture and traditions of the church.

\section{Dialogue of Church and Cultures, A Contextual Theology Effort}

Through the Vatican II document, the church giving her full pledge support to see the cultures as field or terrain for its contextual teaching. The church was fully aware that the revelation of God, where the incarnation of Christ as his culmination being happened in the context of culture. So the church said, "There are many ties between the message of salvation and human culture. For God, revealing Himself to His people to the extent of a full manifestation of Himself in His Incarnate Son has spoken according to the culture proper to each epoch. Likewise, the church, living in various circumstances with time, has used the discoveries of different cultures so that in her preaching she might spread and explain the message of Christ to all nations, that she might examine it and more deeply understand it, that she might give it better expression in liturgical celebration and the varied life of the community of the faithful'. ("Gaudium et Spes," 1965, p. 58)

In line with the above teaching from Vatican II, Pope John Paul II, in the context of Asian heritage of cultures, religions, and traditions, he was giving his words of encouragement. This heritage is undoubtedly not only the matrimony of the Asian people but the world as well. So the Pope said, ".....The most striking feature of the continent is the variety of its peoples who are "heirs to ancient cultures, religions, and traditions." We cannot but be amazed at the sheer size of Asia's population and at the intricate mosaic of its many cultures, languages, beliefs, and traditions, which comprise such a substantial part of the history and heritage of the human family... The church has the most profound respect for these traditions and seeks to engage in sincere dialogue with their followers," (John Paul II, 1999, p. 6).

Based on these particular teachings on church and cultures, we were being a person who is coming from a quite "thick" interwoven between Church and local culture in East Kalimantan. We try 
to share our experience in doing the contextual theology where local culture will be a partner for dialogue. Since the church's teaching are vary to say the local customs, we focused on the topic of Communio Sanctorum theology and the cosmology of Dayak Tunjung Tribe. Using the way of indepth interview method with the respondents from Dayak's artistic side, we have conducted a series of interviews with some respondents and found a deep spiritual thinking and expansive vision of cosmology. We considered that the two traditions, both Catholic on her Communio Sanctorum and the Dayak's cosmology could be in a proper synthesis toward a contextual theology effort. An encountering of these two traditions proved to be an enriching one to both directions, either for the Catholic side or to the Dayak one.

\section{Synthetic theology as a model for theology contextual}

As many of us know, one of the tools in doing contextual theology is by using the models of contextual theology as proposed by Bevans. By using the word model to do contextual theology, Bevans has agreed on some ideas coming from some experts. One of them is Ian Graeme Barbour, a scholar on the relationship between science and religion, who wrote how the model is working. As being cited by Bevans (2016, p. 4), Ian Barbour said that "models and theories are abstract symbol systems, which inadequately and selectively represent particular aspects of the world for specific purposes." In more of his writing in the book title Religion in an Age of Science, he elaborates the idea of a model by saying, "...this view preserves the scientist's practical intent while recognizing that models and theories are imaginative human constructs. Models, on this reading, are to be taken seriously but not literally; they are neither literal pictures nor useful fictions but limited and inadequate ways of imagining what is not observable. They make tentative ontological claims that there are entitiesin the world something like those postulated in the models."(Barbour, 1990)

So, the model is not picturing the whole picture of realities. Model is a way to construct the truth to get the ideal type of existence, either logically constructed theoretical position or an abstraction formed from a particular place. Quoted Avery Dulles in his book Models of Revelation, Bevans (2016) stressed the concept that "amodel is a relatively simple, artificially constructed case which is found to be useful and illuminating for dealing with realities that are more complex and differentiated." We are reminded that the model cannot depict reality, which is full of complexities and varies. Model is a way to disclose the truth, provide an angle of vision. "Models provide a knowledge that is always partial and inadequate but never false and merely subjective," Bevans (2016, p. 30) underlined.

Bevans proposed six models for doing a contextual theology. First, the translation model, presupposed that the essential message of Christianity is supra- cultural or supra-contextual (Bevans, 2016, p. 40). We have to discern what is considered husk and core, be contextual of the gospel, and the 'naked gospel.' Since we have to search the 'receptor situation" for the appropriate terms or actions or story to rewrap the message, the second is the anthropological model, which is the establishment or preservation of cultural identity by a person of Christian faith. Bevans said that "what is important in this model is the understanding that Christianity is about the human person and her or his fulfillment," (Bevans, 2016, p. 54). So, the model pretty much stresses the value and goodness of Anthropos, the human person.

The third is the praxis model of contextual theology, which focusing itself, as Bevans (2016, p. 70) said, "...on identity of Christians within the context, particularly as that context, is understood in terms of social change." This model of theology is a way of doing contextual theology formed by 
knowledge at its most intense level, the level of reflective action. The fourth, the transcendental model, was doing theology as a way of "attending to the affective and cognitive operations in the selftranscending subject," (Bevans, 2016, p. 103). What is essential in this theology model is where someone is taking the transcendental itself as his or her starting point to concern about one's own religious experience and one's personal experience. The fifth is countercultural model, where one who is doing a theology contextual will "take context (experience, culture, social location, and social change) with utmost seriousness.... it warns that context always needs to be treated with a good deal of suspicion," (Bevans, 2016, p. 117). It suspects that the gospel itself containing the cultural elements that need to be purified by searching what is supposed to be a real revelation and, indeed, the message of the gospel.

The sixth is the synthetic model, where someone who is doing theology by putting himself or herself on a "midway between an emphasis on the experience of the presence (context: experience, culture, social location, social change) and the experience of the past (scripture, tradition)" (Bevans, 2016, p. 88). I am using this model on this writing since this model tries to balance between, on one side, to preserve the importance of the gospel message and heritage of traditional doctrinal formulations. While on the other hand, this model acknowledges the vital role that context has played and can play in theology. As Bevans (2016, pp. 90-91) said, "this model reaches out to the resources of other context and other theological expressions for both the method and the content of its articulation of faith." How this model is helping me to do the contextual theology, I like to invite readers to see below how the theology of Communio Sanctorum being synthesized in with the Dayak Tunjung cosmology.

\section{Communio Sanctorum, a new horizon of Church Theology}

As quoted from many sources, the doctrine of Communio Sanctorum was being incorporated in the Apostle's Creed between fifth to sixth centuries. Martasudjita, for example, said that this doctrine of faith took quite a long time came into the Apostle's Creed after the teaching and doctrine on forgiveness of sins and the resurrection. It came to its finalized form somewhere in the sixth century. (Martasudjita, 2013, p. 425). While John Kelman Sutherland Reid reminded that, "Creeds are made when circumstances impose a need to make clear positively what Christianity has to say and negatively to repudiate something. That Christianity does not say, i.e., to expound to the faithful in the time of doubt and repel the traducer in time of heresy," (Reid, 1980, p. 54). But Reid never gives a clear idea in which year precisely the Communio Sanctorum doctrine was incorporated in the Apostle's Creed. He instead asks us not to concern with the year of historical inquiry, but go beyond this, to the exact interpretation meaning of such doctrinal teaching.

Following the flow of shared understanding, most Christian people thinking that the doctrine of Communio Sanctorum is very much related to the communion of saints or in terms of koinonia, the communion of the people of God. Reid explained the conflict idea on this matter between Donatists and Augustine. Reid (1980) said that "the Donatists were rigorists, even moral perfectionists. They thought of the church as a Communio Sanctorum in the sense of consisting of actually saintly people. And from its fellowship, sinners had to be excluded." Against that view, Augustine understood the Communio Sanctorum in a quite broad sense, mainly "to affirm that the celebrant's unworthiness did not impair the validity of the sacraments. In expounding this sacramental emphasis, he amplifies the meaning of communion and refers to 'gifts of the Spirit' that are or will be the common property of all" 
(Reid, 1980, p. 55). This understanding is authentic when we speak about the sacraments, especially Eucharistic Sacrament, where wine and bread are used to be the real objects for the body and blood of Christ.

It is interesting to see what Christin Firer Hinze was putting her idea about the meaning of Communio Sanctorum. In line with the Church teaching and what is being the practice in the Eastern Church, Hinze said, "from the early centuries of the Christian story, the tradition of the Communio Sanctorum has referred to two mysterious relationships. As proclaimed before the communion rite in Eastern churches, Communio Sanctorum refers to the sharing of holy things among holy people (the saints), quintessentially, the sharing of Christ's body and blood in the Eucharistic Liturgy. In its second meaning, the communion of saints refers to the vital spiritual bonds of charity/love, influence, and assistance among all the faithful, living and dead, in the Body of Christ, the church," (Hinze, 2008, p. 46). So, the basic of Communio Sanctorum is the presence of God in spiritual bods between the people and surely to say with all the created things. In this case, the teaching on Communio Sanctorum can be limited no to the people themselves but the whole interwoven relationship between God, His people, and all other creatures.

The interpretation's Elizabeth Johnson about Communio Sanctorum theology explains the doctrinal teaching and liturgical symbol of the communion of saints. As Johnson said, covers all the living and the dead, the life of entire human beings in a special bond and relationship with God, the Creator. Johnson (1999, p. 5) elaborates her idea of Communio Sanctorum as followed, "imagine if you will, a religious symbol that joins all living people who seek the face of God into a circle of mutual companions. Furthermore, that connects this living community with the faithful dead of all ages. It also links them all with Eucharistic bread and wine and through this sacrament with the whole realm of the natural world. Finally, that embraces this totality with the outstretched wings of the creating, redeeming, liberating Spirit of God who unites and lures them further into participation in God's own life."

Johnson based her reflection from the Book of Wisdom, where it is written: "From age to age, she passes into holy souls and makes them friends of God and prophets" (Wis 7:27). Johnson believes that this same Spirit who vivifies and renews the natural world enters into holy souls, and not so holy ones, sanctifying their struggle to be faithful and weaving them all into a sacred community for the sake of the suffering world. From this verse, she divided into three ways of interpretation. Johnson (1999, p. 6) stresses the understanding that Grace of God which creates the truth and holy people in the whole human history. But, the grace of God admittedly not limited to the circle of the sacred people themselves. This grace of God is reaching out to all human beings and creatures so that "within human cultures. Everywhere the Spirit calls persons to seek truth and live in love and justice with others, 'friends of God and prophets' can be found in every tongue and nation, even among religion's cultured despisers".

As the second meaning of the Communio Sanctorum, Johnson interprets what St. Paul said in his letter to Roman, where it is written, "for I am certain of this, neither dead nor life... will separate us from the love of God made visible through Christ Jesus our Lord" (Rom 8:39). Since the communion of saints is not restricted to persons who live and breathe at the present moment but also embraces those who have died. The experience of paschal mystery affirms that Jesus in his whole person and all dimensions of his historical existence has entered into a new and different brilliance of life in the embrace of God. Johnson (Johnson, 1999, p. 9) brings us to the essence of the Christian belief in God 
especially when we face the fate and the existence of the dead, that "persons are not lost in death but are enfolded into the mystery of the gracious being of God which to us is darkness but to them is the fulfillment of their lives in the sphere of the Spirit". In this faith, the saints were those who have arrived home in unspeakable, unimaginable life within the embrace of God. The communion of saints' forges intergenerational bonds across time that sustain faith in strange new times and places. Surrounded by the cloud of witnesses, connected in memory and hope, we learn their lessons of encouragement and cherish in very different circumstances what they cared enough to live and die. The third meaning of Communio Sanctorum on Johnson's thinking is based on the meaning of the word Sanctorum. Following the tradition of the Church, Johnson revives again on two ways to see it.

On the one hand, Sanctorum may be a form of the noun Sancti, in which case the term means 'holy persons.' On the other hand, Sanctorum may just as well be a form of the noun Sancta, in which instance, the term refers to 'holy things' (Johnson, 1999, p. 14). So Johnson (1999, pp. 15-16) concludes that the Communio Sanctorum is a complex, multi-layered reality made up of the Spiritfilled community sharing in each other's lives and in the sacraments, holy people and holy things inextricably linked. For the universe, itself is the primordial sacrament through which we participate in and communicate with divine mystery. Since the same divine creativity that fuels the vitality of all creation also lights the fire of the saint, then 'communion in the holy' includes holy people and a sacred world in interrelationship. Set within the life-giving history of God with the world, the holy community encompasses all creation, past, present, and to come, holy people and the whole natural world imbued with God's blessing, together.

We conclude this topic from the theology point of view that the Communio Sanctorum is a holistic teaching of the Church regarding God's presence in this world. God is a holy God. So, either the persons or the things which are coming and created by the Holy God. He is Holy in their essence or presence or has in their nature as the holiness of God. Correctly, in this way, we may proceed to see how the same God is working through the history of human beings and nature. Since, we may say that God, human beings (seen and unseen), and quality cannot be separated. In this sense, we will see how this concept genuinely alive and being inherited from generation to generation in many nations, tribes, and clan. In the next step of this reflection, we will see how the concept of Communio Sanctorum being present also in such a way in Dayak Tunjung Tribe.

\section{Dayak Tunjung cosmology as a loci theologici}

Dayak Tunjung is one of the Dayak Tribes living in the area of East Kalimantan Province. They are settling in many districts in some regencies, mainly Kutai Barat Regency and Kutai Kartanegara Regency. We may find this tribe staying in some districts like Barong Tongkok, Damaai, Mooq Manoor Bulaatn, Linggang Bingung, Long Iram, Kembang Janggut, Melak, Siluq Nguraai, Sekolaq Darat, Loa Janan, and Kota Bangun. Undoubtedly, many families also settle in the big cities like in Tenggarong, Samarinda, Balikpapan, and Sangata. Those who are staying in the villages like on some districts, as mentioned above, are still practicing their so call "local religion" very actively. Many kinds of shamanism, i.e., Beliant Bawo, Beliant Waweeq, Beliant Sentiu, Alint Taont, Tohooq, Sentangih, Wara, Melas, Mara Genikng to name some variants of its Beliants are still being practice by this tribe in their respective places.

Dayak Tunjung people have based their beliefs on several myths that are being inherited from generation to generation. They have dozens of myths, telling the origin of rules or order, human 
beings, other creatures, shamanism practices (Beliants), the genesis of earth, sky, moon, stars, sun, good and evil spirits, and other of divinity lives. Those myths are usually being used in a very formal way in many rites during the shamanism practices. This practice is a complete and comprehensive way of using the myths since the shaman will be pointing out the materials used for the rites. While doing so, shaman(s) will narrate every myth of every presence material in a particular song or hymn to tell from where it has come, for what purpose it has entered into being and created, and in which way it has to be used in human life in this world or to the world to come (Damianus, 2018, p. 3). While their other means of narrating the myths usually using a non-formal way (not during the performance of the rites) by means of storytelling to the children or others where such practice is also being done from generation to generation.

Myths are the story on how this tribe will see in their logic way out of their long history, the origin of the world and everything in it, the origin of the dozens of Spirit which have their unique roles toward human being and the world itself and all the things which related to the moral and order of society (Madrah, 1997, pp. 1-2). As other anthropology like Mikhail Coomans said, myths explaining about what is to be considered as holy events in the past or some phenomena which had been experienced from time to time by ancestors, even though its historical element cannot be verified using the standard of data verification as what modern people do. But those events and phenomena were being used as a norm for their society. This norm will function not only as an order for the people, but it will serve as a way of explaining the existence of things, either a human being or the things related to them (Coomans, 1987, p. 77). Telling about how Dayak Tunjung Rentenuukng, who are part of the Dayak Tunjung themselves, on how they comprehend their myths, Lahajir said that Dayak people treated myths as their unwritten "holy scripture" since it contains their tradition, believe and order which are being used for their lives' guidelines for generations (Lahajir, 2001, p. 132).

In their myths, Dayak Tunjung shows theirs believe that all created things included divine lives came and have their origin from one God, Nayuq Nyengke Nyuleet [14, p.5]. His name is Nyengke Nyuleet, the descriptive term to express that nobody knows from where his origin is. He is suddenly there. He is in the form of Nayuq, the dark, mysterious figure, the Spirit, a supernatural way, but his presence in this world is still sorely real. He is the goal where human beings were going after their journey in this world. Dayak Tunjung people believe that He has created other divine figures until they have come in the form of human beings, that are Tulur Aji Jangkat and Mooq Manoor Bulaant (Damianus, 2018, p. 15), the first figures of human being, came down from heaven, from a divine life above.

It was not only the human and the other created things that have their origin from divine lives. The myths also telling about all the rules and order as well as rituals were coming from the same source, sacred experiences above. Dalmasius Madrah mentioned that Kilip Tamaan Tauq, the founder of all knowledge, had to travel nine times to heaven to get the order and rules for arranging human beings and the natural life in this world (Madrah, 2001, pp. 18-24). After doing those series of traveling, he was finally granted by divine figures concern for the rules and orders, like the rules of the planting season, rule of matrimony, rule of trial and judiciary, rule of reconciliation, rule of murder and assassination, an order of social life living in a longhouse (lamin), etc. The same to be said as the myth of shamanism like many rites of Beliant. As the respondent told during the interview, Beliant also came into its more or less "complete" rituals like what we can see and experience it today. It has as well its origin from the divine life above (Damianus, 2017, p. 42). Since we can see that the myths 
are genuinely telling us all that the acts of human beings, whatever it will be, always have their interrelation to the immense sense of religiosity in the of Dayak Tunjung belief. So, someone needs to see that those myths are being interwoven into one another, and from that line, we may see the cosmology of this tribe.

The cosmology of Dayak Tunjung people is related to what Eduardo Viveiros de Castro said about cosmology based on animism projection and understanding. Castro understood animism in the context of a cosmology as an ontology that postulates the social characters of relations between humans and non-humans that the space between nature and society is itself social (Eduardo, 2002, p. 311). In this case, Castro sees that humans and animals and the other creatures are all being immersed in the same socio- cosmic medium. It is quite different to compare, for example, how a cosmology sees from the perspective of nature, where everything is related to an organism and in the context of ecological interaction force. The animism cosmology is also different from what Alfred Gell has explained about the cosmology of Polynesian people, which marked by a scheme in which the creation of the cosmos came about through conflict and separation. In this way of cosmology, the Creator God (Ta'aroa) creating the world into the act of separating to be a bi-cameral world, po (night, darkness, dead) and ao (light, life, human activity) (Gell, 2002, p. 291).

However, we have to pay serious attention that, although Dayak Tunjung cosmology is more related to the animism cosmology, yet it is quite challenging to put it in parallel as an animism cosmology point of view offered by Viveiros de Castro above. If we were going back to what the respondents said during the interview, they actually could not make any difference that in this world, only one God is in charge of as most of the monotheism religions dogma brings about. Since the beginning of creation, it seems that there was no creatio ex nihilo concept like what we found in Christian and Jewish tradition of creation. We found that it was true that Nayuq Nyengke Nyuleet was there from the beginning. But the respondents didn't tell us anything that he created the other deity's figures. It was narrated that the other deity's figures seemed already there (Damianus, 2017, pp. 5-11). They were taking their specific role, either in expanding and sculpturing the earth, creating the sky, making the sun, moon and the stars, bring down humans to the earth and giving down order or rules and the rituals. What seems very strong in their cosmology we can find is the deities in their togetherness but remain in a precise role were playing their particular parts respectively on creating and later on managing this world. All we have seen as the real things in this world today are very clear that they have their origin in the deity's world before, and the world itself is still in connecting to the divine life too. Since each reality in this world, including all human beings (especially Dayak Tunjung people), have their guardians and protectors Spirit to make sure that they remain the purpose of being created and made (Damianus, 2018, pp. 10-11).

To sum up, what we can draw, Dayak Tunjung cosmology is that their lives are interwoven with the cosmic. Human beings, together with other creatures and created things are supporting each other, not only for the sake of living harmoniously, happily, and prosperously in this world, but continue to the journey in the world to come. Those who are already living in a different world still have their roles in this world. The sense of living together where the element of divinity is experienced vividly in this world, and it firmly believes the same where someone has left this world after one's death. For those who are still in this world, the dead are not the barrier for being in excellent communication with the unseen and what is considered as deity's life. Sincethe person who left this world will join in a precise way of life, but still could be in contact, either in the form of helping humans during the time of 
needed or pouring blessing when they are asked to do so (Damianus, 2018, pp. 8-9).

\section{Communio Sanctorum and Dayak Tunjung Cosmology, a synthesis effort}

Now, it is time to synthesize the two traditions, the theology of Communio Sanctorum as the Christian tradition, and the Dayak Tunjung cosmology as the other one. Bevans (2016, p. 90) reminds us that in the effort to synthesize the two contexts, one must remember that the fundamental presupposition of the synthetic model is the composite nature of the human context as the context in which men and women live. So, the practitioners of this model hold that every context has both elements which are unique to it and components that are held in common with others. And Bevans (2016, p. 90) goes on with his explanation that the synthetic model emphasizes both uniqueness and complementary. This composite makeup of every culture means that every culture can borrow and learn from every other culture and remain unique. So, we will follow this line in our effort to synthesize both traditions.

In the process of doing a synthetic model to contextualize our theology effort, we would like to define the two traditions into three categorical ways, mainly cosmological category, the ritual category, and the communal one. This way of choosing the three definite is an attempt to focus on some aspects of the two traditions, which we consider still have a significant impact and relevancies toward both communities. By choosing these three categories in our analytical synthetic model, it doesn't mean that we can only have our reflection limited to them. It is a matter of focusing and defining in the sense of limiting ourselves since we are fully aware that the realities we have found in the two traditions themselves are vast and quite vary greatly.

Using cosmology category, we had seen above that in Dayak Tunjung cosmology, before other deity's life came up, Nayuq Nyengke Nyuleet was already there. People believe that He is the maker of all things, the source and the origin of all creatures, including human beings (Damianus, 2017, pp. 56). Although there was no clear explanation about the relation of the other deity's figures came after $\mathrm{He}$ was initially been supposed from Him. Still, people give credence that He was the one who makes others appear in reality. He was the almighty, all-powerful One (Damianus, 2017, pp. 5-6). Since He was and all deity's figures were "living" in the godliness and divinity place, from them came to all creatures, world, sun, moon, stars and finally first human beings in the world named Tulur Aji Jangkat and Mooq Manoor Bulaant who have descended from heaven above.

Since the creatures, including human beings, brought in their nature the life and elements of godliness and divine life, they all have their possibility to help each other. They live in the oneness of cosmic, where the divine and godliness or deity's figures live independently from human beings. They can always be reached at any time, especially when the Dayak Tunjung people require their help accordingly. In many phenomena, the deity's figures will appear to human beings, using many ways for their representation just to confirm the creatures and human beings, that truth that they were living separately. However, still, they also have a unique role in such life and a specific condition.

What we could take as a summary for the cosmological of Dayak Tunjung people is that their sense of religion is alive. This sense of religiosity takes its form in many rituals and being practices in abstinence way (periikng-pojeq/pantang pemali) (Damianus, 2018, pp. 4-5). This is the second category where we can arrive now. The rituals, either for thanksgiving, cure the sick persons, and obituary one, are widely practices in respective districts where Dayak Tunjung was staying. We might say that these vary of rituals are very much part of their life up to the present days. By doing so, they experience again and again that the deity's figures and even their ancestor spirits whom they believe 
have been living happily in heaven keep giving them protection, blessing, and being a guardian for their daily life. The myths are being recited over and over again by shamans to tell the living that the deity's figures are here with us to help us to rebuke the evil spirits and bad luck and to open the possibility of the new way of communication, also maintain the things following their order and rules (Damianus, 2018, p. 6).

The sense of religiosity of this tribe also being observed in their rules and order in society. We considered it as the third category for this contextual theology effort that is communal life. As being stated above, that the rules and orders in their society cannot be seen as the product of a human being only. All regulations and law had been taken from above, from the deity's figures whose roles were mainly for that so that the communal life of people and the entire world will be in harmony toward each other and surely with divine consciousness. Kilip Tamaan Tauq (the Father of all knowledge) was the one who received those rules after being performed the series of travel to heaven, above since his name should be mentioned especially by those who are involved in Besaraaq (get together for any local judiciary matter or resolving the common problems) where the Dayak Tunjung was discussing and making a decision for the betterment of their rule and order observances.

Now we shift to the tradition of Christianity, to see how the three categories work. In Christian cosmology, we believe that God is a creator God who created all things, started from creating heaven and earth (Gen 1:1). Furthermore, He created other things until it came to its culmination: the creation of human beings (Gen 1: 3-27). The Church teaching explains very clearly that, The Word of God and his Breath are at the origin of the being and life of every creature: It belongs to the Holy Spirit to rule, sanctify, and animate creation, for he is God, consubstantial with the Father and the Son. Power over life pertains to the Spirit, for being God, he preserves creation in

the Father through the Son...."God fashioned man with his own hands [that is, the Son and the Holy Spirit] and impressed his form on the flesh he had fashioned, in such a way that even what was visible might bear the divine form," ("Gaudium et Spes," 1965). Pope Francis, I elaborating this teaching by saying that, "As Christians, we are also called "to accept the world as a sacrament of communion, as a way of sharing with God and our neighbors on a global scale. Our humble conviction that the divine and the human meet in the slightest detail in the seamless garment of God's creation, in the last speck of dust of our planet," (Francis, 2015).

While moving forward to the second category of rituals, the Christian tradition celebrating God's presence and central of their faith in the liturgical celebrations. Liturgy is an act of thanksgiving for God's blessing and grace to the human being and the entire world. Since God created human beings, the church teaches that "man is by nature and vocation a divine being. Coming from God, going toward God, man lives a fully human life only if he freely lives by his bond with God," ("Catechism of the Catholic Church," 1994). In the liturgy, the word of God is read, prayer for the petition, and the hymns are said and sung. People of God, as a Communio Sanctorum with the other creatures, are being sanctified again and again by God through the act of His Holy Spirit. People are holy, since God is Holy, and they, through the action of liturgy, lively and openly express their closeness and sense of being one with God, their Creator, and Savior. Through liturgical celebration, God continues His works to sanctify the entire world and human being, so that they will experience his love and care for all.

While the sense of being one with God wherein liturgical celebrations appear is a way where a communal life between human beings and entire life with God will always be maintained. Human 
beings and the whole creatures bring in themselves the element of the divinity of God, the power of God himself. Since in this way of understanding, every human being and everything is holy. Communio Sanctorum is a communal life with God through the Holy Spirit, the source of life, and the existence of human beings and the entire world. Since the scripture tell us that "...the God who made the world and everything in it is the Lord of heaven and earth...." (The Act 17:24). Christian believe that the same God continues His work until now. He doesn't create human beings and the entire world than cut him off from the world's daily life. Just the vice versa, He is a God, who is through His Son, Jesus Christ continues His saving plan to the world, since, as St. Paul said that, "...in him (Jesus Christ) all things were created: things in heaven and on earth, visible and invisible, whether thrones or powers or rulers or authorities; all things have been created through him and for him," (Col 1:16).

What can we draw as the synthetic point on this study now? From the three categories above, one may see that both traditions were saying the same about the origin and the beginning of human beings and this world. The words source and starts here follow the understanding of what Isabell Herrmans said that "origins are events that imply extra-human forces, often situated in a pre-temporal or prehistorical horizon, whereas beginnings emerge against what precedes them, are humanly made and located in time and society" (Herrmans, 2011, p. 190). Both traditions offer the same understanding that God or Nayuq Nyengke Nyuleet is the one who is in charge of this world. This world, human beings, and the entire creatures have their origin in God, a powerful and mighty one. Since they also bring God's image or God's divine life in their existence. This is why all human beings and the other creatures have a possibility and capacity of holy living, which brings them to be part of God's life and part of God's mystery. God's grace, blessings, and a saving plan are always for the entire of human beings and all the other creatures.

In this sense, we may speak the mind of religiosity in both traditions. People who are part of these two traditions feel that they are part of God's life. So, they experience God's presence in their rituals and through Holy Scripture (tempuutn/myth for Dayak Tunjung and Bible for Christian). We might disagree with this model of putting the two in parallel, Bible, and tempuutn, if we see the Bible as something above in value and grade compare to the other one. But, taking into account that both were revealed to the human and both contain the message of refreshing, directing, guidance, warning, and exhortation for human beings. We can see surely and definitely that they have their uniqueness, which each, in this sense, can be put together as something which has the power to retain people to be with God always, their source and goal of life.

Their practice of many rituals and liturgical celebrations might be very different, as the background of them different and unique. To say about the material used in ceremonies is diverse as a similar case compared to the other religions and local beliefs. But, they all finally bring to the same goal, to surrender in God's hand, to ask his blessing and grace, to follow what He has told many people through their traditions from generation to generation, to search His protection in the time if needed, to get His appeal in the epoch of disastrous and distressful. What the main goal to be reached is always to observe His words, asking a pardon and mercy when the mistakes have been made for the sake of happiness and prosperous life, not merely in this world, but in the world to come as well.

\section{Conclusion}

Theological point of view is growing and expanding from time to time. It's happened as a way the Church answers and interprets the sign of the time. Similar to say about the revival of the local cultures 
and traditions in many places and countries as a result of the study in the anthropology and sociology particularly. The restoration of the local customs and traditions have their home and space openly where the countries and local government strive to get more revenue from the tourism sector. It is also being challenged either by the government or international appreciation or even pressure to preserve all the culture and local wisdom tradition elements.

Indeed, the phenomena mentioned above in such a way challenge in the church to find again and again the way how to preserve her traditions and refresh her teaching following the people nowadays, in their respective places and context. We have tried to see how the Communio Sanctorum can explore more precisely and find its more or less parallel way in the local context, especially the Dayak Tunjung cosmology point of view.

We experience that this way of doing theology can help us not to stay in a bias feeling toward others without reaching out to the deeper. It is an open arm way to embrace others without feeling that we are superior in terms of belief and faith compare to the local one. What we have tried to do during the research process was to explore how deep and vast God is working in every human being and created things. Other traditions out there always have something great and valuable to be explored. If Christian faith is supposed to be a universal faith, it has to deal with the universal God and work through human life and history universally.

For the Dayak Tunjung community, this effort of contextual theology will promote their local wisdom, beliefs, and traditions. This effort of contextual theology has a very narrow way of understanding and exploring complex cultures and traditions. It will be exciting if one day, many Dayak Tunjung people will be reaching out to other traditions too so that their own culture will get more highlight and broad horizon. People can also enjoy their many worths and esteem values, which they have been living in through the years.

Finally, it is worth to be quoted as a conclusion of this article where the church sees herself as a part of the Missio Dei of God. To explore other traditions to see God's "working hand" with other groups of human beings. It is an act of understanding that we are on the way of a journey together toward the same God, which is on one side very close to us, but full of mystery on the other side. J. Nelson Jennings has a unique way of reflecting on this topic when he once wrote, "...the Missio Dei, the triune God's commitment to making the world right again. God is the initiator, manager, and sustaining power of that macro project. As such, God deals with all the people involved. All people fundamentally respond to God's dealings in a more basic way than we human beings respond to anyone else or any other created being, object or circumstance". The contextual theology is one out of many ways to understand and get involved in Missio Dei, which we convincingly believe is still working now and tomorrow.

\section{References}

Barbour, I. G. (1990). Religion in an Age of Science. Harper San Francisco, 360.

Bevans, S. (2016). Models of Contextual Theology, Revised and Expanded Edition. New York: Seventeenth Printing, Orbis Books.

Catechism of the Catholic Church. (1994). Retrieved December 5, 2020, from https://www.vatican.va/archive/ENG0015/_INDEX.HTM

Coomans, M. (1987). Manusia Dayak, Dahulu, Sekarang dan Masa Depan. Jakarta: Gramedia.

Damianus, Y. (2017, April 3). Interview with the respondents. 
Damianus, Y. (2018, September 25). Second Interview with the respondents.

Eduardo, V. de C. (2002). Cosmological Deixis and Amerindian Perspectivism. In M. Lambek (Ed.), A Reader in Antropology of Religion. United Kingdom: Blackwell Publishers Ltd.

Francis, P. (2015). Encyclical Letter Laudato Si' Of The Holy Father Francis On Care For Our Common Home. Vatican: Vatican Press. Retrieved from http://www.vatican.va/content/dam/francesco/pdf/encyclicals/documents/papafrancesco_20150524_enciclica-laudato-si_en.pdf

Gaudium et spes. (1965). Retrieved December 5, 2020, from http://www.vatican.va/archive/hist_councils/ii_vatican_council/documents/vatii_const_19651207_gaudium-et-spes_en.html

Gell, A. (2002, U.K.: Blackwell Publishers Ltd). A Reader in the Anthropology of Religion: Ed. Michael Lambek. Retrieved June 25, 2020, from https://www.bookdepository.com/ReaderAnthropology-Religion-Michael-Lambek/9781405136143

Herrmans, I. (2011). Towards the breaking day: An ethnography of Belian curing rituals among the Luangans of Indonesian Borneo. Helsinki: University of Helsinki.

Hinze, C. F. (2008). Over, Under, Around, And Through: Ethics, Solidarity, And The Saints. CTSA Proceedings 66, 33-60.

Huang, P. H. (2011). Towards A Paradigm Shift In Theology: From Euro-Andro- Anthropocentric Salvation To The Redemption Of God's Creation. Theologies and Cultures, Theology Journal, $\operatorname{VIII}(1)$.

John Paul II, P. (1999, November 11). ECCLESIA IN ASIA. Retrieved June 27, 2020, from http://w2.vatican.va/content/john-paul- ii/en/apost_exhortations/documents/hf_jpii_exh_06111999_ecclesia-in-asia.html

Johnson, C. S. J. E. (1999). A Community of Holy People in a Sacred World: Rethinking the Communion of Saints. Retrieved from newtheologyreview.com/index.php/ntr/article/view/

Lahajir. (2001). Etnoekologi Perladangan Orang Dayak Tunjung Linggang. Yogyakarta: Yayasan Galang Press.

Madrah, D. T. (2001). Adat Sukat Dayak Benua dan Tonyooi. Jakarta: Yayasan Rio Tinto, Penerbit Puspa Swara.

Madrah, D. T. (1997). Tempuutn, Mitos Dayak Benuaq dan Tunjung. Jakarta: Yayasan Rio Tinto, Penerbit Puspa Swara.

Martasudjita, E. (2013). Pokok-pokok Iman Gereja, Pendalaman Teologi Syahadat. Yogyakarta: Penerbit P.T. Kanisius.

Reid, J. K. S. (1980). Communio sanctorum, The Sacramental Interpretation. Retrieved June 27, 2020, from https://www.churchservicesociety.org/sites/default/files/journals 